\title{
Conceptualizing Human Stewardship in the Anthropocene: The Rights of Nature in Ecuador, New Zealand and India
}

\author{
Stefan Knauß ${ }^{1}$ (D)
}

Accepted: 11 May 2018 / Published online: 14 December 2018

(c) The Author(s) 2018

\begin{abstract}
In this text I investigate the increasing usage of the Rights of Nature to approach the task of Stewardship for the Earth. The Ecuadorian constitution of 2008 introduces the indigenous concept of Pachamama and interpretes nature as a subject of rights. Reflecting the two 2017 cases of the Whanganui River (New Zealand) and the Gangotri and Yamunotri Glaciers (India), my main argument is that, although the language of individual rights relies on modern subjectivity as well as the constitutionalism of the secular nation state, it is obviously seen as a trans-cultural tool to justify Human Stewardship over the Earth in the Age of Anthropocene. I argue that the new Rights of Nature debate "provides" a straightforward justification of the Stewardship for the Earth and it includes two moments aimed to transcend European Modernity. The Rights Approach justifies obligations towards nature beyond human interests and it appeals to indigenous knowledge as an alternative sphere of argumentation. The relation of this endevor to the Anthropocene is twofold: The indigenous worldviews can now be translated into Rights of Nature because of the two core items of the Anthropocene that are gaining more and more acceptance: the idea of the Earth as a system and of history as a non-linear process. The scientific description of the Earth system offered by the Anthropocene supports holistic narratives of the Rights of Nature and facilitates the recognition of non-Western worldviews. At the same time the Rights of Nature help to clarify the normative claims implicit in the Anthropocene because the integrity of natural items and processes is presented as the explicit reason for a responsible human stewardship towards the Earth.
\end{abstract}

Keywords Rights of nature $\cdot$ Anthropocene $\cdot$ Environmental ethics $\cdot$ Intercultural philosophy $\cdot$ Legal pluralism

Stefan Knauß

stefan.knauss@uni-erfurt.de

1 Seminar for Philosophy, University of Erfurt, Erfurt, Germany 


\section{Introduction}

It's not that we've changed our worldview, but people are catching up to seeing things the way that we see them (Māori Politician Adrian Rurahwe) ${ }^{1}$

To describe the world we are currently living in, the Anthropocene represents a widely acknowledged frame work. The Anthropocene is a key paradigm for debating environmental issues in scientific, political and ethical debates. Its main contribution is a scientific and therefore non-normative theory of the manmade global warming. The presupposed interconnectedness of man and nature introduces a systemic worldview. I argue that this shift to a holistic narrative provides a catalys for the growing acceptance of systemic indigenous worldviews. I investigate three cases where these indigenous worldviews are used to justify a Rights of Nature approach. My claim is that the Rights of Nature might be a useful tool to frame human stewardship in the Anthropocene, on the basis that giving rights to entities that previously were considered as mere objects is the most powerful normative tool of Western modernity.

The concept of right is the strongest language for questioning the fundamental asymmetry of the human relationship to planet earth. I argue that the Rights of Nature present a particular position of agricultural and environmental ethics that sets limits to human agency and justifies an ethos of partnership with the planet all the while recognizing the enormous potential of humanity to alter it. Legal equality is the fundamental presupposition of a symmetric conceptualization of the human relationship to planet earth. The consequences of a rights based approach to agricultural and environmental ethics is a fundamental critique of capitalist practices, which treat nature as a resource. Looking at contemporary cases it becomes clear that the Rights of Nature aim to break what has been called the double internality, the specific movement of how capitalism works through nature and how nature works through capitalism (Moore 2015).

The concept of Right is always related to humanity, since it requires humans to acknowledge or to judge the rights and responsibilities. Nevertheless we can observe an increasing usage of the rights language to recognize non-human entities juridically. The American layer Christopher Stones famously suggested in his 1972 essay "Should trees have standing?" (1972) the attribution of rights to trees, valleys and other features of the environment. The assignment of subjective rights can be regarded as the highest moral-juridical recognition of an entity within the frame of Western modernity. The scope of the paper explores the proliferation of this thought alternated and pushed forward by the narrative of the Anthropocene. Even if the concepts of a 'legal entity' or 'moral personality' are deeply rooted in the Western-European tradition, they are in fact applied in contexts that refer at the same time to non-western traditions. Part of my argument is that this surprising collage of modernity based rights language and indigenous beliefs is obviously not seen

\footnotetext{
1 Quoted from: Davison (2017). Whanganui River given legal status of a person under unique Treaty of Waitangi settlement, The New Zealand Herald, 15 March 2017.
} 
as contradictive but as a very productive relationship. To ascertain whether there really is no contradiction goes beyond the scope of this paper.

I will show that the language of Rights is used in contemporary legal documents to reflect local problems of indigenous communities as well as a global vision of the Anthropocene. The non-utilitarian language of the Rights of Nature is one way to explain the normative claims of the Anthropocene insofar as it characterizes nature as a Rights possessing subject. By analyzing the cases of the Ecuadorian Constitution (2008), the Whanganui River in New Zealand and the Gangotri and Yamunotri Glaciers in India (2017) it becomes clear that the Rights of Nature debate after 2000 shows an astonishing similarity to the Anthropocene: the holistic indigenous worldviews are finally able to connect to the systemic vision promoted by climate-scientists. This incidence gives a rise to the debate of the Rights of Nature that went from romanticims to reality. Roughly said: The Anthropocene fosters the indigenous justifications of the Rights of Nature. The Rights of Nature promote a concept of human stewardship for the Earth that is grounded in the most powerful normative language of Western modernity: the language of individual legal rights.

By expanding the view from the Ecuadorian Constitution (2008) to recent law cases from New Zealand and India (both 2017), the 'multiplicity of worlds' (Nancy 1996, 2007) will be expressed as the transcultural-applicability of the Rights of Nature. In doing so one can observe that the relationship with the other occurs on two levels, among humans and from humanity to nature: On the one hand, various cultures might approach environmental issues in different ways according to their own worldviews that are nevertheless seen as compatible to the language of Rights. On the other hand, this plurality of cultural approaches to environment creates also slightly different forms of relationships to Planet Earth. The case of Ecuador shows a very general approach of nature as such-espressed by the indigenous category of Pachamama. In Ecuador rights are claimed on a constitutional level as a result of decolonial experiment and indigenous movement. The case of New Zealand formulates rights of a river as a result of a struggle between Māori people and the government. The Whanganui River is the most concrete introduction of the Rights of Nature on a local level. It has the least appeal to the international dimension. Nevertheless, it expresses most clearly the idea of the recognition of indigenous worldviews- something, that had been impossible for centuries. India can be seen as a kind of synthesis between Ecuador and New Zealand, since it addresses the functioning of a glacier ecosystem in it's local and global dimension. Also typical for this case is the assemblage of spiritual-indigenous narratives as well extensive references to the international discussion of environmental law.

\section{Defining the Anthropocene}

In this section I give a short introduction to what has been called the Anthropocene. The frame of the Anthropocene is very important to understand the intellectual environment of the Rights of Nature debate. Although the participants do not refer explicitly to the argumentation provided by the Anthropocene, the implicit holistic worldview constitutes a discursive ground for the acceptance of indigenous 
worldviews within the realm of juridical argumentation. The Anthropocene gives a scientific explanation of the interconnectedness of man and nature that can be found in many authochtonous cultures all over the world. This similarity allows for multiple and hybrid justifications of the Rights of Nature.

Following Vincent Blok "The Anthropocene is a new geological epoch, in which the human has become the most influential 'terraforming' factor on Earth. Global warming is one of the main characteristics of the Anthropocene" (2017: 129). The geologists Paul J. Crutzen and Eugene F. Stoermer introduced the term in 2000. The previous definition of the Holocene, the "post-glacial geological epoch of the past ten to twelve thousand years" was introduced by Sir Charles Lyell in 1833 and finally accepted by the International Geological Congress in Bologna in 1885. Crutzen and Stoermer argue that the "mankind's activities gradually grew into a significant geological, morphological force" (Crutzen and Stoermer 2000: 17). The quantitative as well as qualitative expansion of mankind in terms of population growth and consumption has clearly marked the earth system in a tremendous way. Specifically the anthropogenic emissions of carbon dioxide and its effects on the global climate altered what Crutzen calls "nature's behaviour" of the past 10-12 millennia (Crutzen 2002: 23).

Considering the "growing impacts of human activities on earth and atmosphere", Crutzen and Stoermer deem it appropriate "to emphasize the central role of mankind in geology and ecology by proposing to use the term "Anthropocene" for the current geological epoch" (Crutzen and Stoermer 2000: 18). Although identifying a concrete starting point of the Anthropocene seems "somewhat arbitrary", they propose the end of the 18th century, which "coincides with James Watt's invention of the steam engine in 1784" and the worldwide expansion of the textile industry as one of the key features of the industrial revolution (Crutzen and Stoermer 2000: 18).

Timothy Clark, a scholar of environmental humanities, observes: "The term has rapidly become adopted in the humanities in a sense beyond the strictly geological. Its force is mainly as a loose, shorthand term for all the new contexts and demandscultural, ethical, aesthetic, philosophical and political—of environmental issues that are truly planetary in scale, notably climate change, ocean acidification, effects of overpopulation, deforestation, soilerosion, overfishing and the general and accelerating degradation of ecosystems" (Clark 2015: 2). Besides his pessimism about the inflationary usage of the term, that is "vaguely and now in danger of becoming hackneyed" (Clark 2015:1) he sees a conceptual value in marking a critical limit regarding the effects of human action on planet earth. Following Clark, the Anthropocene is a "threshold concept" (Clark 2015: 2, 9, 15).

Once the threshold is marked, the Anthropocene also involves a call to action for many scholars: "On the one hand, it shows our dependence on Earth's carrying capacity for our human existence. This, on the other hand, calls for the transition to a more sustainable future" (Blok 2017). The discussion of the Anthropocene entails both the acceptance of the factual influence of human action on the planet and the imperative to alter our practices and techniques in order to prevent further damage to the earth. The demand to take action involved in the descriptive language of the geo scientist is mostly taken for granted. The constraints on space prevent me from dealing here with the question how to bridge the gap from is to ought within the 
framework of the Antropocene. Given the need to change our relationship to the planet, how should we than transform our normative thinking? How do we express our common obligation to save the earth?

One proposal is the introduction of an ethos based on "non-dualism, non-anthropocentrism, and eco-centrism"(Blok 2014: 325). The concept of ethos refers to a particular lifeform embodying moral convictions as well as a common practices. Since "ethos" grammatically cannot be pluralized, it requires a collectively shared lifeworld, that partly contradicts the fragmentation of the world we are currently living in. The observable multiplicity of worlds demands a less exclusive umbrella concept to encompass the variety of lifeworlds. In the investigated cases the concept of right was able to function as an umbrella that catches different local lifeforms as well as universally shared way to care for the planet. In the following section I will use the cases from Ecuador, New Zealand and India to show how the language of rights formulates a potentially universal concept of planetary stewardship. Typical for the investigated cases is the almost paradoxical interpretation of the indigenous categories in the terms of modern constitutionalism. I argue that this paradoxical movement of the Rights of Nature can be linked to the Anthropocene by referring to its two key features: the systemic vision of the earth (1) as well as the non-linear understanding of history (2).

Crutzen and Stoermer believe that the Anthropocene was anticipated by a number of other scientists starting at latest with G. P. Marshs book Man and Nature (1864), reprinted during the 20th century under the significant title "The Earth as Modified by Human Action" (Marsh 1864). Other precursors of the new concept of the Anthropocene have been identified in Antonio Stoppani $(1873,1887)$, Vladimir Vernadsky $(1924,1929)$ and de Chardin (1925). All of these authors emphasized the enormous impact of humanity on the Environment, although they did not seem to share two basic conceptual innovations, introduced by the concept "Anthropocene" in 2000: firstly the systemic vision of the earth, sometimes is understood as "Earth's metabolism" (Steffen 2000) and secondly the non-evolutionary reading of humankind's geographical and ecological influence as representing a clear rupture with the modern conceptions of a progressive and linear "development" of the Earth's history (Hamilton and Grinevald 2015).

\section{Ecuador's Constitution-From the indigenous movement to Environmental Constitutionalism}

In 2008 the state of Ecuador accepted a new constitution that embraces the Rights of Nature. In referring to Pachamama ("mother earth"), this is the very first adoption of Nature as a subject of rights in the constitution of a modern nationstate. There are five Rights of Nature Articles in Ecuador's Constitution. The section "Rights Entitlement" states: "Persons and people have the fundamental rights guaranteed in this Constitution and in the international human rights instruments. Nature is subject to those rights given by this Constitution and Law" (Ecuador 2008: Art. 10). In the special chapter "Rights for Nature" we read: "Nature or Pachamama, where life is 
reproduced and exists, has the right to exist, persist, maintain and regenerate its vital cycles, structure, functions and its processes in evolution" (Ecuador 2008: Art. 71).

The constitution is part of a political renovation that Ecuador experienced in 2007 with the first indigenous president Rafael Correa. The strong influence of the indigenous movement that fought for the political and economic recognition of the autochthonous people provided the basis for social innovation. In this time the term buen vivir (or vivir bien) was coined, as an alternative Latin American conception of the good life, according to the andean concepts of sumaq kawsay (Quechua) or suma qamaña (Aymara). The Latin American scholar Catherine Walsh attributed to buen vivir a very high potential to break with developmental thinking: „It offers perhaps the possibility to challenge the development paradogmas ${ }^{2}$ of the past and their colonial, imperial, and dependence-based designs and aspirations"(Walsh 2010: 16). In so doing, buen vivir refers to the holistic world view of the Andean peoples and breaks with the modern understanding of man and nature: "There is no separation between human life and the environment, and human lives cannot be separated from each other. Harming the environment is harming one's own life, and failing to enable others to live in dignity is preventing oneself from living in dignity" (Deneulin 2012: 9).

The Yasuni-ITT project was initiated in 2007 by Rafael Correa. Ecuador offered the United Nations a perpetual suspension of oil extraction in the Yasuni National Park "Ishpingo-Tambococha-Tiputini" (ITT). In return, the activists were asking for payments of $\$ 3.6$ billion from the international community. The goal of the initiative was the transition to a sustainable form of economy in order to maintain the biodiversity as well as the living environment of the indigenous peoples in the region. The rationale was furthermore to avoid the $\mathrm{CO} 2$ emissions of more than 800 million barrels of oil, which clearly would have contributed to international climate politics. The initiative ultimately failed in 2013, when the Ecuadorian government decided to extract the oil. What remained was the strong impetus to approach global climate politics and economics in a different way. The engagement for an alternative globalization was leading also to the constitution with a groundbreaking aspirance. "With a transforming constitutional frame of reference like Montecristi's, the task lies in democratically facing the struggle for life, which is what is really at stake. And, incidentally, an international strategy will need to be put into action to empower the avant garde principles contained in the Ecuadorian Constitution and possibly boost the Universal Declaration of Rights of Nature" (Acosta 2010: 8,9).

From the discussion of constitutional assembly on April 29th 2008 we know that the argument of a possible transformation towards a Declaration of the Rights of Nature served to convince the sceptics of the Rights of Nature even in Ecuador (Asamblea Constituyente 2008). The member Rafael Esteves argued: „We should be proud of creating a true advancement in constitutional right' and '[...] to demonstrate to Latin America that here, in this Andean country, as they call us, in this small country, we can indeed add to the evolution of international constitutional right" (Asamblea Constituyente 2008: 78). Taking into account that Latin America

\footnotetext{
${ }^{2}$ The term "paradogma" indicates a paradigm that has almost the status of a dogma.
} 
was confronted with it's assumed backwardness throughout the colonial history the idea of being a Norm Entrepreneur (Stuenkel 2013) must have been very convincing for the members of constitutional assembly. Following this line, Acosta Esteves further argued that, the constitution of Ecuador could introduce a novelty that "after 20 or 30 years [...] will be commonplace" all over the world (Asamblea Constituyente 2008: 78). ${ }^{3}$

The Ecuadorian case can be related to a wider discussion among philosophers and lawyers about the Rights of Nature. Within this framework the example of Ecuador moved the discussion of Earth Jurisprudence to the stage of Global Environmental Constitutionalism (Rühs and Jones 2016). Earth Jurisprudence has been defined as "a philosophy of law and human governance that is based on the idea that humans are only one part of a wider community of beings and that the welfare of each member of that community is dependent on the welfare of the Earth as a whole" (Cullinan 2011: 13). The recent development of "Global Environmental Constitutionalism" is seen as "a new mindset around international law and governance with the environment as a universal concern" (Rühs and Jones 2016: 174). The German lawyer Klaus Bosselmann goes even further when he argues for the priority priority of the Rights of Naure. According to him, "Eco Constitutionalism is "the aim for shifting the environment from the periphery to the centre of constitutions" (Bosselmann 2015: 185).

Bosselmann and others have been arguing since the 1980s for the legal recognition of nature within constitutional law. The Ecuadorian case from 2008 showed the possibility to pass this kind of legislation, when an indigenous movement coincided with an interesting appeal to international climate politics, informed by the narrative of the Anthropocene. Reflecting on the historical dimension of the Rights of Nature debate after 2000, Judith Koons states: "Earth Jurisprudence is an emerging field of law that calls us to pause as we enter the twenty-first century to consider the ground under our feet and the teachings bearing down on us from the horizon" (Koons 2008: 263). She defines Earth Jurisprudence as a "search for wisdom, that would not endorse short-term economic gain, but would regulate human activities to support mutually beneficial relations among humanity, other-than-human species, and Earth processes' (Koons 2012: 389).

The pre-supposed interconnectedness of man and nature is captured by the systemic vision of the earth, that we discussed in the previous section. It is also a key feature of the Rights of Nature: "Human beings, as well as all other animate and inanimate matter on the planet Earth, are physically composed of the same elements that constituted the originating stardust. Evolution biologists and quantum physicists have documented not only that everything on Earth is composed of the same elements, but also that the elements are intimately related in a "dance of interactions". The interactions are not simply among living matter, but among animate and inanimate entities. Indeed, many scientists argue that life is less a question of type of matter and more a question of process" (Koons 2008: 288).

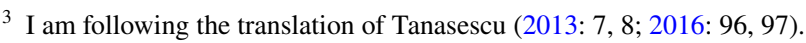


Following Hamilton and Grinevald (2015) we were able to highlight the systemic view on the planet, stated by the Anthropocene. Following Koons (2008, 2012) this new holistic narrative is a key feature also of the Rights of Nature debate after 2000. The scientific approaches of "evolution biologists and quantum physicists" mentioned by Koons demonstrate a structural similarity to the holistic vision of Pachamama that Ecuador introduced in its constitution from 2008. The introduction of a-broadly speaking-metaphysical monism based on an ontology of process that Koons describes metaphorically as "stardust" or elements in a "dance of interaction" is seen as the novelty of the Rights of Nature debate after 2000. It is important to understand the Ecuadorian case within the broader context of what has been called Earth Jurisprudence or Global Environmental or Eco Constitutionalism. Whatever has to be said about the pragmatic dimension of the constitution as a means of political struggle, it shows nevertheless - for the first time in history-the acceptance of the Rights of Nature on constitutional level. The legally binding recognition of the Rights of Nature advanced the debate to the stage of Global Environmental Constitutionalism. In the following section I argue that this development may have inspired also two cases of non-constitutional rights in New Zealand and in India. The cases presented are similar to Ecuador since they use a local indigenous worldview to address universally recognized environmental issues. The hybrid connection of modern rights and indigenous beliefs can be read as a very special answer to the Anthropocene question of how to approach human stewardship after having acknowleged the enormous and sometimes hazardous impact of humanity.

\section{Whanganui River in New Zealand}

In March 2017, the Whanganui River in New Zealand was recognized as a living being and granted full human rights. The third longest river of the country is traditionally linked to the Whanganui iwi tribe and plays in important role for the culture of the Māori people. The communities' connection to the river is expressed by their saying: "E rere kau mai te awa nui nei, mai i te kāhui maunga ki Tangaroa, ko au te awa, ko te awa ko au," which translates as "The river flows, from the mountains to the sea, I am the river, the river is me" (Young 2017). Traditionally the Māori tribe relates its wellbeing directly to the wellbeing of the river and treats it like an ancestor. Since 2017 this cosmovision is officially accepted in terms of jurisprudence. It took the Māori tribe 140 years of struggle for the recognition of the Whanganui River as a legal entity.

Gerrard Albert, the lead negotiator for the Whanganui iwi tribe said "treating the river as a living entity is the correct way to approach it, as an indivisible whole, instead of the traditional model of the last 100 years of treating it from a perspective of ownership and management" (Roy 2017). The Māori tribe considers the river as part of its community: harming the river means harming them. This approach deeply reflects the worldview of the Māori tribe that regarded themselves as part of the universe, at one with and equal to the mountains, the rivers and the seas. This view rejects the idea of mastery over the natural world and provides an integral view for human beings as a part of it. The Treaty Negotiations Minister Chris Finlayson said: 
"I know the initial inclination of some people will say it's pretty strange to give a natural resource a legal personality. But it's not stranger than family trusts, or companies or incorporated societies" (Davison 2017). Since family trusts, companies or incorporated societies are artificial persons, they need representatives to perform their legal personality. The same occurs with the Whanganui River: a guardian from the crown and a representative from the Whanganui iwi will stand together for its interests.

In New Zealand, a river was given the same legal status as a person for the first time, but it was not the first time that a natural entity was accepted by the law. Already in 2014, the national park Te Urewera in the North Island was recognized as a legal entity. Te Urewera has been named a national park in 1954 and since 27 July 2014 it became "a legal entity" with "all the rights, powers, duties, and liabilities of a legal person" (New Zealand 2014: 16). The so called Te Urewera Act is seen as "legally revolutionary [...] on a world scale" (Ruru 2014). Besides regular management plans, the national park has a special board that is responsible "to act on behalf of, and in the name of, Te Urewera" (Ruru 2014). The board is set up by representatives from various tribes and has the responsibility to reflect also their customary values, laws and traditions. Since already the National Parks Act 1980 recognizes the "intrinsic worth and for the benefit, use, and enjoyment of the public", the 2014 addition is the recognition of the national parks boundaries as culturally and spiritually important to the iwi tribe. Therefore, the Te Urewera Act demonstrates a new bi-cultural way of articulating the importance of national park lands for multiple reasons ranging from science to cultural.

The Māori specialist and legal scholar Jacinta Ruru concludes: "National park lands encase the lived homes of Indigenous peoples. Today, the law reflects a new societal goal that seeks to reconcile with Indigenous peoples for the past wrongs of taking their lands and denying them the very means to be true to themselves, their ancestors, and their grandchildren. National parks have the potential to play an instrumental role in committing to this reconciliation journey. National parks are symbolic of our national identity and our future, and the parks contain Crown lands that thus enable the Crown to lead in implementing a new way of thinking about owning and managing lands including national parks" (Ruru 2014).

The long lasting struggle for the rights of Whanganui River that started in the 1870 s clearly involved iwi peoples' interest to settle at the river and to receive financial compensation for former land claims by the state (Shuttleworth 2012). The surprising part of the acceptance of the legal status is not the negotiation of land claims in the first place but the legal recognition of a cosmological narrative like the one of the Māori tribe by a modern nation state, that is regarded as compatible with the language of personhood and individual human rights. Therefore, the recent development is an example of "protecting the cosmology that protects the environment" (Magallanes 2015), a double blinded strategy that gains stronger environmental norms through the recognition of non-western worldviews.

Particular to the case of New Zealand is the focus on the river. The "whole of river' approach (Bosselmann 2017) is different to the constitutional view of Ecuador and raises the conceptual question of the intrinsic value that can be attributed to a river. According to Bosselmann, four intrinsic values are directly drawn from the 
indigenous literature: "1. Ko te Awa te mata puna o te ora-The River is the source of spiritual and physical sustenance. 2. E rere kau mai te Awa nui mai te Kahui Maunga ki Tangaroa-The great River flows from the mountains to the sea. 3. Ko au te Awa ko te Awa ko au-I am the River and the River is me. 4. Nga manga iti, nga manga nui e honohono kau ana, ka tupu hei Awa Tupua-The small and the large streams that flow into one another and form one River" (Bosselmann 2017: $165)$.

Taking together Ecuadors constitution and the Whanganui River in New Zealand, we can learn that obviously indigenous pressure groups, their land claims and there longing for political representation contributed a lot to the juridical manifestation of the Rights of Nature. It further seems to be the case that the Rights of Nature debate is strongly related to local problems where particular political conflicts are decisive for the implementation of the idea of nature as a legal entity. Even if we rely on this reading of the Rights of Nature as a means of political struggle, "protecting the cosmology that protects the environment" changes the structure of human stewardship. The holistic structure of the Māori cosmovision treats the river as a living entity with intrinsic values that are recognized in terms of rights. Once these local indigenous narratives are accepted in legal texts they offer a non purely anthropocentric justification of stewardship for certain environmental features.

My guiding question for the next section is if this local realization of the Rights of Nature can be related to worldwide issues such as climate change and global warming. The question at stake here is not less than the universal dimension of the Rights of Nature debate as a possible normative approach to broadly recognized problems formulated by the Anthropocene.

\section{The Gangotri and Yamunotri glaciers in India}

Only a few days after the Whanganui River case was decided, the Gangotri and Yamunotri glaciers in India were declared living entities by the Uttarakhand High Court. The two glaciers are considered sacred by the indigenous peoples and their acceptance as legal entities includes wide parts of the Himalayas and the rivers Ganga and Yamuna flowing out of the two glaciers in the Himalayas. On March 202017 the High Court declared "the Glaciers including Gangotri \& Yamunotri, rivers, streams, rivulets, lakes, air, meadows, dales, jungles, forests wetlands, grasslands, springs and waterfalls, legal entity/legal person/juristic person/juridical person/moral person/artificial person having the status of a legal person, with all corresponding rights, duties and liabilities of a living person, in order to preserve and conserve them. They are also accorded the rights akin to fundamental rights/legal rights" (Margil 2017).

I want to address this last case study from a methodological point of view because its shows several interesting features of the Rights of Nature debate. I will outline again the pragmatic dimension on a local level, as well as the connection to climate change issues on the global level. Another reason for engaging with this case is the elaborated argument about rights subjectivity, made by the judges, that entails as well a concept of Stewardship. 


\section{Two Outstanding Judges and the Climate Change-Connecting the Global and the Local}

The judges main reason must have been the aim of securing the very existence of the Glaciers and the related rivers endangered by global warming, climate change and pollution. In India, most of the rivers are polluted by urban settlements, farming pesticides and industrial effluents freely flowing into the water, despite stringent laws. The two judges Rajiv Sharma and Alok Singh made the following argument: "The past generations have handed over the 'Mother Earth' to us in its pristine glory and we are morally bound to hand over the same Mother Earth to the next generation" (Jagati 2017).

On the basis of the biographies of the justices Rajiv Sharma and Alok Singh, who were responsible for declaring Ganga and Yamuna living entities, the Hindustan Times journalist Anupam Trivedi calls them "environment crusaders" (Trivedi 2017). Both judges started their careers in 1982 and we know about their strict environmental policy from 2016 on. In November 2016 they opposed glacier taxes for tourists. One day before declaring the glaciers legal entities, they called the Uttarakhand Pollution Control Board to blame hotels, ashrams and industrial units for wasting the Ganga River. I am not sure if "environment crusaders" is the right expression to frame the engagement of the two judges. It certainly seems as though they are critical of mass tourism, as can be highlighted in another case from November 2016, in which they banned liquor in three districts, most probably in order to protect traditional shrines from being misused.

One could easily argue that it just takes regional conflicts, like it was the case in the two previous examples of Ecuador and New Zealand, and ambitious justices to promote the Rights of Nature as a means of individual interests. I think one cannot deny this strategic dimension of the attribution of rights, but two points are more interesting for my own argument. On the one hand the use of the language of Rights of Nature might be strategically motivated, but the language itself is not a utilitarian one. On the other hand the cases, however delicate they might be, do show clearly that Rights of Nature went from utopia to reality in the sense that they are de facto accepted by an ordinary institution of modern nation states.

My argument in the remainder of the text will be that both, the non-utilitarian character of individual rights as well as the acceptability of such a language, are creating a normative surplus in order to confront universal problems like global warming and climate change. The idea of a normative surplus expresses the notion that rights possess their own conceptual sphere of normativity. Once they are acknowledged they create obligations and opportunities that are not anymore identical with concrete political or economical interests that might have motivated their very acceptance in the first place. This notion of Rights is similar to Ronald Dworkins conception of individual rights as "political trumps" (Dworkin 1977: XI).

One important source to justify the Rights of the Glaciers is a report the NASA Earth Observatory gave in 2001. To highlight the shrinking of the Gangotri Glacier the scientists argued: "Currently $30.2 \mathrm{~km}$ long and between 0.5 and $2.5 \mathrm{~km}$ wide, Gangotri glacier is one of the largest in the Himalaya. Gangotri has been receding since 1780, although studies show its retreat quickened after 1971. [...] Over the last 
25 years, Gangotri glacier has retreated more than $850 \mathrm{~m}$, with a recession of $76 \mathrm{~m}$ from 1996 to 1999 alone" (NASA 2001).

The NGO Community Environmental Legal Defense Fund (CELDF) which assisted Ecuador and more than 30 communities in the United States in advancing the Rights of Nature into law, considers the case of the Indian glaciers as an important step forward for the growing Rights of Nature movement. The director of the institution Mari Margil stated that "In declaring that ecosystems are persons, the High Court is recognizing that nature is capable of having rights. This is a critical step forward to transforming nature from being considered property under the law, to being recognized as possessing inherent rights as healthy, natural ecosystems." The Rights of Nature are seen as necessary to secure the ability of ecosystems to remain healthy and thrive. According to this position, ecosystems should not only be considered as available resources for human use but as living entities with inherent rights. Following activists like Marit Margil: "The collapse of ecosystems and species, as well as the acceleration of climate change, are clear indications that a fundamental change in the relationship between humankind and the natural world is necessary" (Margil 2017). The argument for the inherence of rights can-as we already saw in the cases of Ecuador and New Zealand-be provided by an indigenous cosmovision. The need to change our relation to nature as argued by theorists of global climate change and the earth-system analyses is another way to justify it. This second type of argumentation can be seen most clearly in the example of India we are currently dealing with.

In addition to the strong influence of local indigenous rights movements that defend natural features in order to process their cultural self determination, the case of the glaciers Gangotri and Yamunotri clearly relates to worldwide problems like global warming and humanly caused climate change. The glaciers are not only important for the fresh water supply of the Indian people and the indigenous culture of various tribes, they are also seen as a symbol for global climate problems in general. Studies like the one mentioned above from the NASA Earth Observation are showing the importance of the glaciers both as indicators of climate change and as environmental features to prevent dysfunctions of local, regional and global ecosystems. The science discourse about climate change and possible ways to slow down or even stop global warming is amplified by the engagement of transnational NGOs like the Community Environmental Legal Defense Fund (CELDF). They contribute the idea of nature as a legal entity as a normative tool to solve environmental problems.

\section{Understanding Mixed Motives and the Character of Rights and Stewardship}

To deepen our understanding of the concepts of Stewardship, Rights of Nature and the relation between both concepts, it is necessary to deal with the specific argumentation of the judges. In the following passage I will analyses the two most important reports of the debate. The High Court of Uttarakhand at Nainital dealt with the Writ Petition (PIL) No. 126 of 2014 on March 20, 2017 (High Court of Uttarakhand at Nainital 2017a) and the Writ Petition (PIL) No.140 of 2015 on March 
30, 2017 (High Court of Uttarakhand at Nainital 2017b). Both minutes do contain on 78 pages vast references to international environmental law, political and ecological issues of the Himalaya regions, religious insights of Hindu people as well as transcultural notes about political and environmental initiatives.

The character of my analyses is a discursive one that focuses on the ethical and scientific narratives employed by the judges to make their juridical argument work. I am less interested in the juridical details of the procedures as such. In the first subsection I argue that the multiplicity of sources and perspectives involved in the argumentation of the judges can be interpreted as a type of border thinking. In the second subsection I want to show the detailed understanding of the term juristic person that the judges apply and of the proposed concept of Stewardship.

Both cases explicitly draw on Hinduism to support the sacred status of the Ganges and Yamuna rivers. At the same time, the description of a juristic person is deeply rooted in European Western modernity. Therefore the two analysed texts can be located "at the intersection of the sacred and the legal" as Erin O'Donnell, a specialist of Environmental Law from the University of Melbourne has been arguing. Following this insight, we should draw attention to the way in which the combination of indigenous knowledge and modern rights language is articulated, since it can be said that these judgments "present powerful examples of the increasing relevance of rights-centred environmental protection" (O’Donnell 2017: 137).

On March 20, the judges stated: "Rivers Ganges and Yamuna are worshipped by Hindus. These rivers are very sacred and revered. The Hindus have a deep spiritual connection with Rivers Ganges and Yamuna. According to Hindu beliefs, a dip in River Ganga can wash away all the sins. The Ganga is also called 'Ganga Maa'. It finds mentioned in ancient Hindu scriptures including 'Rigveda"' (High Court of Uttarakhand at Nainital 2017a: 4).

It's typical of that case that the traditionalist position is supplemented by statistical and scientific knowledge. The judges refer to the NASA material that we cite in the previous section of this paper: "Gangotri Glacier is situated in District Uttarakashi of the State of Uttarakhand. It is 330.2 kilometres long and between 0.5 and $2.0 \mathrm{~km}$ wide. It is one of the largest Glaciers in the Himalayas. However, it is receding since 1780. The receding is quick after 1971. According to the images of NASA, over the last 25 years, Gangotri glacier has retreated more than 850 meters, with a recession of 76 m from 1996 to 1999 alone. River Ganga originates from Gangotri Glacier" (High Court of Uttarakhand at Nainital 2017a: 5).

The textual analysis presents strong evidence that scientific as well as religious arguments seem to be equivalent for the judges, since they decided to express the local religious importance of the rivers and the function of this area for the planets ecosystem in one single sentence: "Both Ganga and Yamuna Rivers are revered as deities by Hindus. Glacial Ice is the largest reservoir of fresh water on earth" $(6,30$ March 2017).

I would like to make two points here: Firstly, the judges are arguing in an inbetween space to create a hybrid document. Since they refer to legal and religious structures at the same time, their narration represents a kind of border thinking (Anzaldúa 1987; Mignolo 2012) drawing from very different kinds of sources that on the first glance might seem to be incompatible or even contradictory. 
Acknowledging this, we can further observe that they not only cross the border of the science versus religion dichotomy. We can at the very least add the dimensions local versus global, modern vs. traditional, and holism versus individualism. The judges are referring their findings to a wide range of authors and positions, they mention the importance of trees from the Indian Mythology and in the religious life of indigenous people from different countries. Another topic is the role of globalization, the position of the poor countries, as well as a critique of developmentalism as such.

The Kenyan Environmentalist and Alternative Nobel Prize Winner of 2004, Sri Wangari Muta Maathai is cited with the following words: "To a very large extent, I think, globalization is a threat to the environment in countries that are not developed industrially, in countries that are poor, because these countries are looking towards globalization as an answer, and believe that corporations will get them out of poverty. Very often, these corporations simply do business, take their profits and go- leaving their problems behind. I want to say to them that unless we can appreciate that the planet is very small, that part of the problem is that you think you are doing something to a distant person, a different part of the world. But it will eventually come back to you. We must expand our concept of home, to make sure we see beyond our individual countries. The very first astronauts told us that they were overwhelmed by the fact that they could not see boundaries, and they felt a strong urge to come back home. Home was that small blue ball we've become familiar with on television, a small ball beyond borders. The whole planet is our concern, wherever we are. They are little things we can do in our lives, we can listen, we can consume less, because this is the only home we have, and we should leave it clean and green for future generations" (High Court of Uttarakhand at Nainital 2017b: 7).

The overall picture is completed by arguments about biodiversity and concrete conservation strategies for the alpine zone of the Himalaya. The biological statements about the ecosystem do mention the role of special components and species as well as their way of functioning together (High Court of Uttarakhand at Nainital 2017b: 11-17). Another important type of reference is the declarations of international environmental law involving also documents from the United Nations. These declarations are cited at the length (High Court of Uttarakhand at Nainital 2017b: 17-26). The so-called Stockholm Declaration (United Nations 1972) marks the kick off of the common globalized environmental policy. Other important steps are Resolution 37/7 of the UN General Assembly from 1982 which includes a World Charter for Nature and of course the Rio Declaration from 1992.

The trade and exploitation of species of wild fauna and flora is another topic addressed by judges. Particularly interesting is the Chipko Movememt from the 1970s. The movement from Uttarakhand gained world wide attention when mostly women started embracing trees to stop the deforestation. The non-violent movement was also inspired by Mahatma Gandhi and got its name from the hindi word "chipko" that means to "hold" or to "keep" something. The role of indigenous knowledge as well as the factor of social movements launching for world wide visibility show a clear resemblance to the investigated cases in Ecuador and New Zealand. 
Besides this connection of the movement to global environmentalism activities, it contains moreover a very specific reference to Buddhism, translated by the judges into a political community of the non-human: "The trees in India are worshipped as incarnations of the goddess [...]. The goddess of the forest, Aranyi, has inspired a whole body of texts, known as 'Aranyi Sanskriti'. It means, "the Civilisation of Forest". The metaphoric political body related to the religious sacrification of trees is then translated into the language of rights: "Trees and wild animals have natural fundamental rights to survive in their natural own habitat and healthy environment" (High Court of Uttarakhand at Nainital 2017b: 41).

\section{Juristic Person and Stewardship}

In the statement from March 20, 2017 the Judges argue for what we can call the contingency of juridical personhood: "The very words "Juristic Person" connote recognition of an entity to be in law a person which otherwise it is not. In other words, it is not an individual natural person but an artificially created person which is to be recognised to be in law as such"(High Court of Uttarakhand at Nainital 2017a: 7). They follow historical examples to show that the term "person" is not necessarily congruent with the category "human being", since for instance slaves in ancient European times did not have the status of persons. The judges highlight a few historical evidences for this argument i.e., the distinction of "natural person" and "legal person" in the Roman law as well as the the introduction of cooperations as "artificial persons" that are nevertheless treated as "legal persons". Consequently, the judges opt for a concept of legal personhood that does not derive from "natural" capacities like the freedom of the will, the ability to reason or to speak. The refutation of the internalist strategy to bound subjective rights to facilities of the (human) is completed by the externalist strategy that refers to the legal structure as a frame of definition: "We may, therefore, define a person for the purpose of jurisprudence as any entity (not necessarily a human being) to which rights or duties may be attributed" (High Court of Uttarakhand at Nainital 2017a: 9).

Two important points for our discussion of the Rights of Nature are following for the judges: On the one hand, stewardship is a very common way to deal with the rights and duties of legal persons that cannot stand for themselves. Children and artificial persons are the standard examples to claim the necessity of stewardship. On the other hand, the judges are making a utilitarian and therefore anthropocentric claim about the Rights of Nature. "A juristic person can be any subject matter other than a human being to which the law attributes personality for good and sufficient reasons. Juristic persons being the arbitrary creations of law, as many kinds of juristic persons have been created by law as the society required for its development" (High Court of Uttarakhand at Nainital 2017a: 10-11). What the judges have in mind is a progressist argument, namely, that the attribution of rights follows the requirement of social evolution. Nevertheless there remains the necessity to identify "good and sufficient" reasons to introduce new rights bearers into the legal context.

Consequently, the spiritual and physical contributions of the rivers for society are reiterated. Since they are important for Indian people, they should be protected. 
Interestingly, the judges do not see a contradiction between what has been called anthropocentrism and biocentrism. ${ }^{4}$ In order to serve the societies' interests best, a fully fledget legal status should be attributed to the rivers. Justifying human stewardship for the planet according to the judges means giving reasons in the interest of human beings by not making human interests the reason of the justification. In other words: Considering nature or certain features of the ecosystems as subjects of rights they are withdrawn from the immediate and absolute disposal of human beings in order to fulfil goals of the society that can be justified with "good and sufficient reasons". In the case of India the recognition of the worldview of Hindu people as well as ecological arguments for the functioning of ecosystems are seen as "good and sufficient reasons".

\section{Consequences}

Having considered the cases of the Wahnganui River (New Zealand) and the Gangotri and Yamunotri Glaciers (India) in the context of attributing Rights of Nature in 2017, I want to conclude with a philosophical outlook. Calling nature a subject of rights has different aspects. The Rights of Nature provide a "deeper" justification of environmental protection because the most powerful normative language of Western modernity is chosen for this protection: the language of subjective rights. The language of rights has the advantage to present our normative claims in a rather transparent and functional way (Kaufmann 2016). From the above analyses we can learn that although Rights are never free of context, they do not require any particular context to remain valid. Once they are established through political struggles they have the power to justify or the prevent various future political actions. They create a space of normativity on their own that we have called "normative-surplus". I suggest the similarity to the formulation "rights as trumps" of Ronald Dworkin, since rights can trump political discussions by giving self-sufficient reasons to different arguments. Within the realm of legal argumentation, "having the right" does not need further explanations as to why. Attributing rights than means establishing intentionally normative boundaries to political struggles.

The examples from Ecuador, India and New Zealand reflect in very particular ways the suitability of the rights language in various cultural contexts. This transcultural applicability appears to be even stronger if we take into account that the concepts 'legal entity' or 'moral personality' are related to very comprehensive indigenous worldviews, traditional beliefs and local practices.

By referring to the Anthropocene we understood the current tendency among climate scientist to speak about the Earth as a system and to envision the history of this system as a non-evolutionary and non-linear process (Hamilton \& Grinevald

\footnotetext{
4 The Preamble of Ecuadors Constituion shows a similar structure: "We women and men, the sovereign people of Ecuador RECOGNIZING our age-old roots, wrought by women and men from various peoples, CELEBRATING nature, the Pacha Mama (Mother Earth), of which we are part and which is vital to our existence [...]" (Ecuador 2008).
} 
2015). These two theoretical perspectives bridge the gap between modern science and some specific indigenous worldviews. The Anthropocene influenced the Rights of Nature debate in the following way: By introducing a broadly accepted scientific narrative of planetary integrity, it offers a comprehensive non-indigenous worldview to relate human action to the planetary processes. This presupposed integrity of the planet or certain environmental features is translated from science into law by referring to the concept of subjective rights. The Rights of Nature are able to make the implicit normative claims of the Anthropocene explicit. Rights are like a shortcut to express our conviction that an entity needs to be protected. Once this shortcut gathers the acceptance of non-European worldviews as well as indigenous cosmovisions and is accepted, it requires stewardship, just like children, cooperations and artificial persons do. The advantage of the rights language is to express most clearly the basic structure of stewardship: arguing in the interest of the rightsholder is fundamentally different from arguing in one's own self-interest. The very grammar of planetary stewardship is clarified by making the planet the reason of human action.

Our analyses of the Rights of Nature debate and its most recent political developments demonstrated that both secular European-Western societies as well as countrys like Ecuador, India and New Zealand with their indigenous pressure groups have particular motivations to introduce the Rights of Nature. The growing acceptance of the Anthropocene does on the one hand create a discoursive environment that facilitates the acceptance of holistic descriptions of the earth. On the other hand, the juridical manifestation of the Rights of Nature can be seen as a response to the lag of normative principles that the Anthropocene has. Stemming from the realm of descriptive science, the theories of planetary boundaries and environmental tresholds has to be translated into the normative sphere of law and morality in order to formulate guiding principles for political action.

Ecuador went from an indigenous social movement to the project of environmental constitutionalism. The Whanganui River in New Zealand does not appeal to the constitutional level and dimension of international environmental law. It is more likely to interprete it as a result of a long-lasting litigation between the crown and the Māori people. What is significant for my argument is that the acceptance was obviously possible in 2017. The iwi politician Adrian Rurahwe from New Zealand framed the argument that way: "It's not that we've changed our worldview, but people are catching up to seeing things the way that we see them" (Davison 2017).

The Rights of Nature make reasons for planetary stewardship explicit by introducing systemic categories of the Anthropcene as well as particular non-Western worldviews. Although the reinterpretation of nature uses the traditional modern vocabulary of rights, it is informed by biological concepts like the ecosystem as well as traditional spiritual concepts of a man-nature unity. The art historian and cultural critic T. J. Demos comments on the rights of nature thus: "this legality has deep roots in Indigenous cultural and religious traditions" (Demos 2015: 8). In 2011 Pablo Solón Romero, the former Ambassador of the Plurinational State of Bolivia declared to the United Nations: “To speak about Mother Earth's rights challenges the entire legal system on which this capitalist system is based. This is why we insist on talking about rights. Someone who kills someone else goes to jail, but if you pollute a river, nothing happens to you. We have to be accountable. The key issue is 
to make us accountable in relation to our Earth system" (Dawson 2011). Although the rights of nature discourse is tied to the project of Decolonizing Nature (Demos 2016), the normative surplus of the Rights of Nature discourse is our accountability towards nature.

\section{Conclusion}

The aim of this article was to discuss the connections between the Rights of Nature and the Anthropocone. My analysis centered on three cases. Besides all their differences, these cases illustrate an evolution and proliferation of the Rights of Nature. I argue that the growing acceptance of the Rights of Nature is implicitly fostered by the Anthropocene. By scientifically defining the integrity and the interconnectness of planetary processes, the Anthropocene offers a widely accepted non-religious understanding — broadly speaking - of the connection between man and nature. By doing so, the globalization of the Rights of Nature debate, which at the same time represents a reassessment of different indigenous worldviews, is enhanced by the Anthropocene. The advantage of the Rights of Nature debate is to make the implicit normative claims of the Anthropocene explicit and thereby accessible to discursive argumentation. At the same time the Rights of Nature debate gives a deeper moraljuridical justification of planet stewardship. It helps to formulate the paradox of planet stewardship, which acknowledges and uses the asymmetry of humanity and nature. The model of stewardship proposed most clearly in the case of India refers to what I call the rights as shortcuts approach. I am arguing that we do not necessarily have to attribute metaphysical qualities like personality, free will or the ability to speak to make sense of rights. In particular, the Indian case refers to the contingency of juridical personhood. According to the judges, rights are a means of reasonable societal goals. The Rights of Nature are attributed to nature as a whole, certain entities like rivers or glacial ecosystems. Pragmatically we can understand a right as a cipher for a set of serious problems we are facing as well as a set of justifications to attribute rights to an entity. The Rights of Nature in particular reduce the complexity of problem scenarios and solution strategies that are posed by the Anthropocene. Giving an entity rights is a stop of argumentation to the question "why should we take care of it?". Human stewardship for the planet is both required and justified by the Rights of Nature, since the very grammar of stewardship implies an entity that we should take care of.

Open Access This article is distributed under the terms of the Creative Commons Attribution 4.0 International License (http://creativecommons.org/licenses/by/4.0/), which permits unrestricted use, distribution, and reproduction in any medium, provided you give appropriate credit to the original author(s) and the source, provide a link to the Creative Commons license, and indicate if changes were made.

\section{References}

Acosta, A. (2010). Toward the universal declaration of rights of nature: Thoughts for action. AFESE Journal, 24(1). 
Anzaldúa, G. (1987). Borderlands: La frontera (vol. 3). San Francisco: Aunt Lute.

Asamblea Constituyente (2008). ACTA 040. Transcript Plenary Discussion of April 29th 2008.

Blok, V. (2014). Reconnecting with nature in the age of technology: The Heidegger and radical environmentalism debate revisited. Environmental philosophy, 11, 307-332.

Blok, V. (2017). Earthing technology: Toward an eco-centric concept of biomimetic technologies in the Anthropocene. Techné: Research in Philosophy and Technology, 21, 127-149.

Bosselmann, K. (2015). Global environmental constitutionalism: Mapping the terrain. Widener Law Rev., 2015(21), 1-24

Bosselmann, K. (2017). The principle of sustainability transforming law and governance. Routledge.

Clark, T. (2015). Ecocriticism on the edge: The Anthropocene as a threshold concept. London: Bloomsbury Publishing.

Crutzen, P. J. (2002). Geology of mankind. Nature, 415(6867), 23.

Crutzen, P. J., \& Stoermer, E. F. (2000). The “Anthropocene”. Global Change Newsletter, 41, 17-18.

Cullinan, C. (2011). A history of wild law. In P. Burdon (Ed.), Exploring wild law: The philosophy of earth jurisprudence (pp. 12-23). Kent Town: Wakefield Press.

Davison, I. (2017). Whanganui River given legal status of a person under unique Treaty of Waitangi settlement, The New Zealand Herald, 15 March 2017. http://www.nzherald.co.nz/nz/news/artic le.cfm?c_id=1\&objectid=11818858,26. April 2017.

Dawson, A. (2011). The rights of mother nature. http://ashleydawson.info/2011/04/21/the-rights-ofmother-nature. 10.10.2017.

de Chardin, P. T. (1925). L'Hominisation. Introduction à une étude scientifique du Phénomène humain. Paris, 6 mai, inédit. (In: Oeuvres, t. 3, La Vision du Passé. Paris: Seuil, 1957, pp. 75-111. English translation in Teilhard de Chardin, 1967).

Demos, T. J. (2015). Rights of nature: The art and politics of earth jurisprudence. Santa Cruz: Santa Cruz University.

Demos, T. J. (2016). Decolonizing nature: Contemporary art and the politics of ecology. Berlin: Sternberg Press.

Deneulin, S. (2012). Justice and deliberation about the good life: The contribution of Latin American buen vivir social movements to the idea of justice. University of Bath Centre for Development Studies Working Paper No. 17. https://doi.org/10.2139/ssrn.2401884.

Dworkin, R. (1977). Taking rights seriously. Cambridge: Harvard University Press.

Ecuador (2008). Constitution.

Hamilton, C., \& Grinevald, J. (2015). Was the Anthropocene anticipated? The Anthropocene Review, 2(1), 59-72.

High Court of Uttarakhand at Nainital (2017a). Writ Petition (PIL) No. 126 of 2014, 20 March 2017.

High Court of Uttarakhand at Nainital (2017b). Writ Petition (PIL) No. 140 of 2015, 30 March 2017.

Jagati, K. (2017). Uttarakhand high court declares Gangotri, Yamunotri glaciers as living entities. Hindustan Times 31 Marc 2013. http://www.hindustantimes.com/india-news/uttarakhand-high-court-decla res-gangotri-yamunotri-glaciers-as-living-entities/story-q1e7sjBnAGefEKT5cpezkO.html. 26 April 2017.

Kaufmann, M. (2016). Recht. Berlin/Boston: Walter de Gruyter GmbH \& Co KG.

Koons, J. E. (2008). Earth jurisprudence: The moral value of nature. Pace Environmental Law Review, 25,263

Koons, J. E. (2012). At the tipping point: Defining an earth jurisprudence for social and ecological justice. Loyola Law Review, 58, 349-390.

Magallanes, C. (2015). Māori cultural rights in aotearoa New Zealand: Protecting the cosmology that protects the environment. Widener Law Review, 21(2), 273-328.

Margil, M. (2017). India court declares "Personhood" of glaciers and ecosystems. Press Statement, 3 April 2017. http://celdf.org/2017/04/pr-india-court-declares-personhood-glaciers-ecosystems/. 27 April 2017.

Marsh, G. P. (1864). Man and nature. Reprint: (1965) edited by David Lowenthal, Cambridge, Massachusetts.

Mignolo, W. D. (2012). Local histories/global designs: Coloniality, subaltern knowledges, and border thinking. Princeton: Princeton University Press.

Moore, J. (2015). Capitalism in the web of life. London, Verso Books.

Nancy, J. L. (1996). The muses. Palo Alto: Stanford University Press.

Nancy, J. L. (2007). The creation of the world, or globalization. New York: Suny Press. 
NASA (2001). Earth observatory, Gangotri Glacier, Himalaya. https://earthobservatory.nasa.gov/IOTD/ view.php?id=4594. 26. April 2017.

New Zealand (2014). Te Urewera Act, Public Act 2014 No 51.

O'Donnell, E. L. (2017). At the intersection of the sacred and the legal: Rights for nature in Uttarakhand, India. Journal of Environmental Law, 30, 135-144.

Roy, E. A. (2017). New Zealand river granted same legal rights as human being. The Guardian. 16 March 2017. https:/www.theguardian.com/world/2017/mar/16/new-zealand-river-granted-same-legal-right s-as-human-being.

Rühs, N., \& Jones, A. (2016). The implementation of earth jurisprudence through substantive constitutional rights of nature. Sustainability, 8(2), 1-19.

Ruru, J. (2014). Tūhoe-Crown settlement-Te Urewera Act 2014. Māori Law Review. October 2014, http://Maorilawreview.co.nz/2014/10/tuhoe-crown-settlement-te-urewera-act-2014/. 26 April 2017.

Shuttleworth, K. (2012). Agreement entitles Whanganui River to legal identity, New Zealand Herald. 30 August 2012. http://www.nzherald.co.nz/nz/news/article.cfm?c_id=1\&objectid=10830586.

Steffen, W. (2000). An integrated approach to understanding Earth's metabolism. IGBP Newsletter, 41, $9-16$.

Stone, C. D. (1972). Should trees have standing, toward legal rights for natural objects. Southern California Law Review, 45, 450-501.

Stoppani, A. (1873). Corso di Geologia, vol. II, Geologia stratigrafica. In Bernardoni, G., \& Brigola, E. G. (eds), 72 The Anthropocene Review 2(1).

Stoppani, A. (1887). Sulla Cosmogonia Mosaica. Triplice saggio di una esegesi della storia della creazione. Milan: LF Cogliati.

Stuenkel, O. (2013). Brazil as a norm entrepreneur: The responsibility while protecting. In: E. P. Hamann \& R. Muggah (Eds.), Implementing the responsibility to protect: New directions for international peace and security? (pp. 59-62). Igarapé Institute.

Tanasescu, M. (2013). The rights of nature in Ecuador: The making of an idea. International Journal of Environmental Studies, 70(6), 846-861.

Tanasescu, M. (2016). Environment, political representation and the challenge of rights: Speaking for Nature. New York: Springer.

Trivedi, A. (2017). Meet the Uttarakhand high court judges who made Ganga, Yamuna living entities. Hindustan Times, April 03, 2017. http://www.hindustantimes.com/dehradun/meet-the-uttarakhan d-high-court-judges-who-made-ganga-yamuna-living-entities/story-6QhkGfhcMTxbtdManbmE KN.html. 25.05.2017.

United Nations (1972). Declaration of the United Nations conference on the human environment.

Vernadsky, W. I. (1924). La Géochimie. Paris: Librairie Félix Alcan.

Vernadsky, W. I. (1929). La Biosphère. Paris: Librairie Félix Alcan.

Walsh, C. (2010). Development as Buen Vivir Institutional arrangements and (de) colonial entanglements. Development, 53(1), 15-21.

Young, D. (2017). Whanganui tribes-Ancestors, Te Ara, the Encyclopedia of New Zealand. http://www. TeAra.govt.nz/en/whanganui-tribes/page-1. 27 April 2017.

Publisher's Note Springer Nature remains neutral with regard to jurisdictional claims in published maps and institutional affiliations. 